The Journal of Society and Media, October 2020, Vol. 4(2) 298-318

https://journal.unesa.ac.id/index.php/jsm/index

E-ISSN 2580-1341 and P-ISSN 2721-0383

Accredited KEMENRISTEK/BRIN No.148/M/KPT/2020

DOI: 10.26740/jsm.v4n2.p298-318

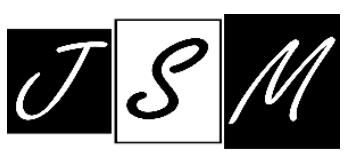

\title{
Parental Mediation of Children's Risky Experiences with Digital Media
}

\author{
Patience Ada James ${ }^{1}$, Jude Terna Kur ${ }^{2 *}$ \\ ${ }^{1}$ Department of Mass Communication \\ Faculty of Languages and Communication Studies \\ Ibrahim Badamasi Babangida University, Lapai, Niger State, Nigeria \\ Email: adaniyajames@gmail.com \\ ${ }^{2}$ Department of Information and Media Technology \\ School of Information and Communication Technology \\ Federal University of Technology, Minna, Niger State, Nigeria \\ Email: jude.kur@futminna.edu.ng
}

\begin{abstract}
Children's use of digital media is associated with risky experiences, a situation warranting parental mediation. Previous studies on parental mediation of children's digital media use, conducted in advanced countries in Europe, America and Asia with rich experiences of children's digital media use, examined only specific risks and rarely focused on effectiveness of the mediation strategies adopted. The present study investigated parental mediation of children's risky experiences with digital media in an African setting, focused on four categories of risks and measured the effectiveness of adopted mediation strategies. Objectives of the study were to identify the mediation strategies parents applied in mediating risks (conduct, content, contact and commercial) encountered by children in the use of digital media, and ascertain the consequences of the mediation strategies. The study, a survey, used a sample of 265 parents drawn from a population 863 academic and non-academic staff members of Ibrahim Badamasi Babangida University, Lapai, Niger State, Nigeria. Parental Knowledge and Intervention in Children's Risky Experiences with Digital Media Questionnaire (PKICREDMQ), designed by the researchers, and successfully scaled through validity and reliability tests, was used to generate data. Findings revealed that the parents adopted mainly two mediation strategies - restrictive and active.
\end{abstract}

Keywords: children, digital, parents, parental mediation, risks

Paper type: Research paper

*Corresponding author: jude.kur@ futminna.edu.ng

Submitted: 2020-05-19; Accepted: 2020-10-29; Published: 2020-10-30

Cite this document: James, Patience Ada, and Jude Terna Kur. (2020). Parental Mediation of Children's Risky Experiences with Digital Media. The Journal of Society and Media, 4(2), 298-318. DOI: 10.26740/jsm.v4n2.p298-318 


\section{INTRODUCTION}

Today's generation of children is surrounded and immersed in the digital environment (Chassiakos et al. 2016), which appears natural and smooth for the children (Goh, Bay, and Chen 2015). With social, market and technological innovations, children's use of digital media is active. The use is partly dependent on the child's social and demographic variables, and varies by location, equipment, and frequency of use (Bako and Tokes 2018). Very importantly, the use is associated with various risks. According to Bottino et al. (2015), the digital space brings new risks and pressures for young people. Bullying is among the commonest risks. As in traditional forms of bullying, exposure to cyberbullying is varied, such as the rapid creation and sharing of abusive messages and comments, the spread of rumours, the exclusion of victims from online groups and various other harassments.

Content, communication and behavioural risks are also the case with the digital lives of children to a high scale. Livingstone, Mascheroni, and Staksrud (2017) observe that children's use of technology carries content risks (displaying annoying images), communication risks (receiving unwanted information from strangers), and behavioural risks (cyber-attacks). Survey results reveal that children below seven years have limited online activities (Bottino et al. 2015; Nikken and Jansz 2014). As such, they are more protected from the diverse contents which older adults are exposed and are designed to contain commercial risks. Compared with younger children, children over 8 years old gradually expand their digital media activities. As observed by Livingstone et al. (2015) and Livingstone et al. (2017), those children tend to begin using various social networking sites and playing online games, which invariably exposes them to bigger risks. New activities not only bring unique experiences to children, they also challenge families who need to respond dynamically to their development.

Evidence from studies of traditional media supports the link between children's media use and unhealthy behaviours. Alcoholism, smoking and serious sexual intercourse in television and movies have been found to be linked to the occurrence of these behaviours (Robertson, McAnally, and Hancox 2013. There is growing evidence that these effects are also evident in digital media. Research (Hinduja and Patchin 2010; Moreno et al. 2016) shows that teenagers' social 
media use is associated with illegal drinking, ill-treatment, illegal use of drugs, illicit and risky sexual practices, and other inappropriate behaviours like self-harm and eating disorders.

Bruni et al. (2015) investigated the relationship among technology use, adolescent sleep quality and age before puberty. Results showed that poor sleep quality among adolescents was associated with increased use of the mobile phone and use of many devices in the bedroom, while poor quality of sleep before puberty was associated with increased vacation time. Similarly, Lemola et al. (2015) have reported association between electronic media use before sleep and sleep disorders and depression in adolescents.

Sexting is a grave challenge to adolescents. It is defined as the transmission of nude or semi-abstract images through electronic means and explicit text messages (Collins et al. 2017). An estimate of about 12 percent of teenagers between 10 and 19 years of age have been involved in sexting (Moreno et al. 2016). Sexual messages are gendered inclined and have negative psychological and social consequences, which have a relationship with direct harassment, especially for girls (Rasmussen, Ortiz, and White 2015). Unfortunately, the internet is an avenue through which children are exploited for sexual assault. Predators online reach children through email, social networks, online games and chat rooms. The anonymous cyberspace environment has exacerbated child trafficking for the purpose of private and commercial gains, and sexual grooming and abuse. For example, children may be tricked or forced into sexual activity to establish online relationships with these criminals and produce child pornography (Guo and Nathanson 2011).

Blum-Ross and Livingstone (2016) summarize risks associated with children's use of digital media by categorizing the risks into four classes: Conduct, content, contact and commercial risks. Examples of conduct risks are bullying, 'sexing' and misuse of personal information. Content risks appear in the form of pornography, violence, racism, and false or misleading content. Contact risks include 'stranger danger', stalking, harassment and impersonation. Commercial risks are come in the form negative advertising, excessive or hidden marketing, and in-app purchases or scams. The present study focuses on these four classes of digital media-induced risks. 
Risks associated with children's use of digital media have attracted the interest of major stakeholders in child development with a view to mitigating the risks. One of the major stakeholders in this regard is parents. Parents as an important child socializing agent have a huge role in acting to minimize these risks. Parental monitoring and supervision of tech-savvy children is a difficult task, since children surpass their parents in acquisition and exercise of digital skills (Tripp 2011). Similarly, many digital media devices are personal and mobile. This makes it difficult for parents to understand the activities of children with digital media (Clark 2011). Children, it is argued, are more involved in the digital media technology than parents (Banaji and Buckingham 2013; Livingstone et al. 2017).

As a primary agent of socialization and caregivers, parents are duty-bound to keep an eye and oversee what children do with digital media so as to guarantee children's safety with the technology (Ho and Zaccheus 2012). This is known as parental mediation, and is defined by Kur, Orhewere, and Agudosy (2011) as strategies adopted by parents to mitigate the effects of undesirable media use by children. Early parental mediation researches (Nathanson 1999; Valkenburg et al. 1999; Warren 2005) identified three primary strategies of parental mediation, which include active, restrictive, and co-use. Active mediation involves parentchild discussion of media content, restrictive mediation concerns parents' rulemaking on children's media use, and co-use is parents' shared use of media with children with a view to motivating responsible use by the children. Another strategy came with the digital age and that is technical mediation or parental controls, which is the use of technology (filters and monitoring software) to control children's use of digital or internet-enabled media (Clark 2011; Durak and Kaygin 2020; Chang et al. 2019). Scholars have identified other parental mediation strategies which include monitoring, active-co-use, interaction restriction, and participatory learning (Clark 2011). These strategies actually fall within the three traditional parental mediation strategies of active, restrictive and co-use. Thus, the present study focuses on active, restrictive, co-use and technical parental mediation strategies, which are the mutually exclusive types of parental mediation strategies found in literature. 
A number of studies exist on the subject matter of parental mediation of children's unsafe experiences with digital media. Most of it shows the strength and weaknesses of different mediation strategies in mediating children's risky experiences with digital media. Rasmussen, Ortiz, and White (2015) studied the relationship between active mediation and pornography use by children. They found that active mediation of pornography reduces the negative indirect effects of children's exposure to pornography and prevent future pornography use. This illustrates the strength of active mediation.

Active mediation is not strong in all cases; it has proved to be a weak mediation strategy in some cases. One such case is shown in the study embarked upon by Smahelova et al. (2017) to identify the relevant factors in mediating definite risks and benefits associated with children's use of digital technology. The result of the study indicated the preference of parents to be silent with children about unsafe aspects of digital technology. This shows a weakness of active mediation.

Livingstone et al. (2015) embarked on a study to determine how parental education and household income influence mediation strategies parents adopt to intervene in their children's approach to digital media. They found that parents, especially those who lacked confidence, expertise or experience in the use of digital media, did not use technical mediation in managing children's digital media use for safety purposes. The weakness of technical mediation is suggested here.

Bako and Tokes (2018) carried out an exploratory qualitative study to determine how Romanian parents perceive risks associated with children's digital lives and how they mediate the risks. Findings revealed that Romanian parents were unaware of the risks their children could have been exposed to, and that they have not been engaging in co-use of the technology with the children. This illustrates the none-use of co-use mediation.

Aierbe, Oregui, and Bartau (2019) studied parents' perception of children's video gaming and the mediation strategies adopted in ensuring children overcome risks associated with video games. They found that parents used more control-based and restrictive strategies in mediating children's risky video playing than general support or instructive strategies. Hence, the study illustrates the potency of restrictive mediation. Another study which illustrated the effectiveness 
of restrictive mediation was that by Chang et al. (2015), which investigated the interplay of internet addiction, cyber bullying, drug use, and depression on parental mediation. It was found that children's addiction to the Internet is associated with pure bullying, drug addiction and depression, while restrictive mediation by parents is associated with decreased child addiction to the Internet and pure bullying.

Restrictive mediation is not always effective even though it is largely used. This is the case with the study conducted by Sasson and Mesch (2014) to determine the influence of parental mediation on adolescents' involvement in risky online acts. Findings indicated that Israeli parents used mostly restrictive measures in their mediation attempts. The more the parents used restrictive mediation, the more the children engaged in online risk activities. This suggests that children always find ways to bypass restrictive mediation, and restrictive mediation deteriorates parent-child relationship.

Blum-Ross and Livingstone (2016) investigated parental mediation strategies utilized in managing the digital lives of children, and found that the choice of parental mediation strategies varies among parents. While some parents prefer the use of parental controls, others favour monitoring and restrictions, active and co-use strategies. This finding makes a case that no mediation strategy is superior over the others; the effectiveness of a mediation strategy is dependent on the mediation situation (child factors, parental factors and medium factors), as observed by Kur, Iorpagher, and Melladu (2019) in their proposed model of parental mediation for child political socialization.

From the foregoing, it is clear that all studies of parental mediation of children's experience with risky digital media content were conducted in America, Europe, Oceania and Asia; none in Africa which experiences comparatively low level of digital media use (Kemp 2018; Watkins 2019). The novelty in the present study is that it investigates parental mediation of children's risky experience with digital media in an African setting. Another gap identified in the reviewed literature is that the studies focus on one or a few specific risks; not on as many risks as are associated with children's use of digital media. The present study focuses on four categories of risks - conduct, content, contact and commercial risks. This broader approach to digital media risks has the tendency to explain 
parental mediation of children's risky experiences with digital media deeper. Similarly, with the exception of the study by Sasson and Mesch (2014), all the studies reviewed did not measure the effectiveness of the mediation strategies studied; they identified the strategies and stopped at that. The present study is designed to identify parental mediation strategies used and go ahead to determine their effectiveness.

\section{METHOD}

Theoretical framework. Parental mediation theory (PMT) forms theoretical backing for this study. The assumption of the theory is that different interpersonal communication strategies are tools through which parents use to intervene so as to ease the adverse consequences of the media on young ones (Clark 2011). The theory explains that the interpersonal interaction which exists between parents and children contribute in socializing the children in the use of media technologies. The emergence of the theory is attributed to the rising adverse effects of the media, and the grave need for parents to contribute in easing the effects (Kur and Essien 2014). Parental mediation theory, even though was originally based on children's television use, has come to include digital media. In relation to the present study, the theory assumes that parents adopt any or a combination of active, restrictive, co-use and technical mediation strategies to mitigate the unhealthy practices of children with digital media.

Objectives. The present study focuses on the extent to which parents mediate the digital media use of children with a view to mitigating the risky experiences associated with the use. The objectives of the study therefore are to: (1) identify the mediation strategies parents apply to mediate risks (conduct, content, contact and commercial) children encounter in the use of digital media, and (2) ascertain the consequences of the utilized mediation strategies.

Method. The study adopted survey design, with a sample of 265 drawn from a population of 863 academic and non-academic staff members of Ibrahim Badamasi Babangida University (IBBU), Lapai, Niger State, Nigeria. The sample was drawn from a sample size table suggested by Krejcie and Morgan's (1970). The sampling procedure included proportional stratified, disproportional stratified, purposive and accidental sampling techniques. First, the researchers created two strata: academic and non-academic staff. For each stratum, a sample proportional 
to the population of the stratum was drawn. Thus, for academic staff with a population of 290, a proportional sample is 89 . The population of the nonacademic staff was 573 and the sample proportional to the population is 176. A reason for the use of proportionate stratified sampling was to ensure the sample was objectively spread across the different strata (academic and non-academic staff) of the population as much as possible. Next the researcher used disproportional sampling to distribute the sample equally to all academic departments (for academic staff) and all non-academic units (for non-academic staff). Thus, for each of the 29 academic departments in the University (Agricultural Extension, Agronomy, Animal Production, Crop Production, University Farm, Biochemistry, Chemistry, Computer Science and Mathematics, Geography, Microbiology, Physics, Food Sciences, Biology, Geology, Continuing Education, Counselling Psychology, History and International Relations, Science Education, Sports and Human Kinetics, Mass Communication, French, English Language, Arabic, Accounting, Sociology, Business Administration, Political Science, Public Administration, and Economics), three academic staff members were studied except the last two departments where four were studied for no specific reason other than making up the sample total.

For the non-academic units in the University (Bursary; Library; Registry; Audit; Consultancy; General Studies; Health Services/Clinic; Information and Communication Technology; Physical Planning, Development and Maintenance; Security and Students Affairs), 16 staff members from each of the 11 nonacademic units were studied. The use of disproportionate stratified sampling became imperative at this stage because it was cumbersome using proportionate stratified sampling (which produces a more objective sample than disproportionate sampling technique) because of the large number of academic and non-academic units in the University studied (population). Next, each academic and non-academic staff member sampled was purposively drawn on a condition that he or she was a parent. The researchers went to each academic department and non-academic unit, the first staff members they met accidentally were asked if they were parents and were willing to participate in the study. Only those who said they were parents and agreed to participate in the research were studied. The use of purposive and accidental sampling techniques at this stage was 
obvious because the study targeted parents, and not every member of the population was a parent. As much as possible, participants responded to the questionnaire and returned it on the spot. In a few cases where on-the-spot response and return of the questionnaire was impossible, the researchers returned a few days after to collect the completed copies of questionnaire.

The average age of the sample was 45.5 years which varied from 20 to 60 and above. Male members of the sample dominated their female counterpart in a ratio of 7:3. In terms of educational qualification, those with Masters Degree dominated by 33.7 percent. They were followed by those with Bachelor Degree and Higher National Diploma (30.2\%), Ordinary National Diploma/National Certificate of Education (18\%), Doctor of Philosophy (15.7\%), and secondary school certificate $(2.4 \%)$ in that order.

The study used a self designed questionnaire to generate data. Titled Parental Knowledge and Intervention in Children's Risky Experiences with Digital Media Questionnaire (PKICREDMQ), the questionnaire was designed for a larger study on parental knowledge and intervention in children's digital media use. It is divided into two sections - A and B. While Section A measured demographic variables (sex, age, educational attainment and marital status), Section B addressed thematic issues. The thematic issues that were of concern to the present study are parental mediation strategies used to mediate children's risky experiences with digital media use and consequences of the parental mediation strategies used.

To measure strategies of parental mediation used in mediating children's risky experience with digital media, respondents were provided with four statements, each representing one type of parental mediation strategy. The statements are: (1) I install filters \& monitoring software on digital devices used by children (Technical Mediation), (2) I set rules on the amount \&/or time children use digital media, permit or forbid children from accessing certain types of digital media content and punish children who violate the rules (Restrictive Mediation), (3) I discuss aspects of digital media content with children, either during or after exposure to digital media content (Active Mediation), and (4) I use digital media with children without any discussion about its contents (Co-use Mediation). To each of the statements, respondents were required to pick one option from a range of options (never, very low, low, high, and very high). Risky 
James: Parental Mediation of Children's

experience is defined in this study in agreement with Blum-Ross and Livingstone (2016) as the negative effects or outcomes experienced by children as a result of their engagements and encounters with digital media. Risky experiences are categorized into four classes as follows: Conduct risks, which encompasses misuse of personal information, bullying, or 'sexing'; content risks (pornography, violence, racism, deceitful or untruthful content), contact risks (danger from unfamiliar, nuisance, harassment or imposture) and commercial risks (advertising, undue promotion, unwarranted or secret marketing, in-app purchases or rip-off).

To measure consequences of the mediation strategies, the same statements $(1-4)$ above are repeated and respondents are requested to indicate their opinion on the level of success in using each of the parental mediation strategies in eradicating or reducing risky experiences associated with children's use of digital media. Response choices include: Very unsuccessful, unsuccessful, successful and very successful. Consequence of parental mediation strategies is defined as the results of the mediation experience - whether the result is successful and rewarding or unsuccessful and unrewarding in assisting to eradicate or minimize children's risky experiences with digital media.

The questionnaire successfully scaled through validity (content validity) and reliability (test re-test) tests, with a reliability coefficient of 0.97 . The questionnaire was manually administered on a face-to-face basis so as to guarantee easy and timely collection of data. Out of 265 copies of the questionnaire administered, 255 were returned and found usable, yielding 92.5 response rate. Data analysis was based on this response rate. SPSS version 25 was used to analyze data collected.

\section{RESULTS AND DISCUSSION}

\section{a. Parental Mediation Strategies used to Mediate Children's Risky Experience with Digital Media}

Results in respect to strategies used to mediate children's risky experience with digital media show that all the strategies studied were used at varying degrees. Restrictive mediation was used more than the other three mediation strategies. It was followed by active, co-use and technical mediation strategies in 
that order. While restrictive and active mediation strategies were applied to a high level, co-use and technical strategies were not as shown in Table 1 below:

Table 1

Respondents' use of parental mediation strategies in mediating children's risky experiences with digital media

\begin{tabular}{lllllcl}
\hline \multicolumn{1}{c}{$\begin{array}{c}\text { Parental } \\
\text { mediation } \\
\text { strategies }\end{array}$} & $\begin{array}{c}\text { Never } \\
\text { F (\%) }\end{array}$ & $\begin{array}{c}\text { Very } \\
\text { low } \\
\text { F (\%) }\end{array}$ & $\begin{array}{c}\text { Low } \\
\text { F (\%) }\end{array}$ & $\begin{array}{c}\text { High } \\
\text { F (\%) }\end{array}$ & $\begin{array}{c}\text { Very } \\
\text { high F } \\
(\%)\end{array}$ & $\begin{array}{c}\text { Total } \\
\text { F (\%) }\end{array}$ \\
\hline $\begin{array}{l}\text { Technical } \\
\text { Mediation }\end{array}$ & $158(62.0)$ & & & $15(5.9)$ & $7(2.7)$ & \\
$\begin{array}{l}\text { Restrictive } \\
\text { Mediation }\end{array}$ & $10(3.9)$ & $17(6.7)$ & $21(8.2)$ & $52(20.4)$ & $155(60.8)$ & $255(100)$ \\
$\begin{array}{l}\text { Active Mediation } \\
\text { Co-use Mediation }\end{array}$ & $20(7.8)$ & $31(12.2)$ & $43(16.9)$ & $69(27.1)$ & $92(36.1)$ & $255(100)$ \\
\hline
\end{tabular}

Table 1 shows that the dominant parental mediation strategies used by the parents to mediate children's risky experiences with digital media were restrictive and active mediation strategies. As many as $205(81.2 \%)$ parents indicated that restrictive mediation strategy was highly employed. Similarly, as many as $161(63.2 \%)$ respondents indicated that the active mediation strategy was highly employed. Contrary, many of the parents said they have never used technical mediation (62\%) and co-use mediation (38\%) strategies. Only a few respondents said they used technical (8.6\% to a high level and $29.1 \%$ to a low level) and couse $(34.9 \%$ to a high level and $27.1 \%$ to a low level) strategies.

This finding agrees with those of Aierbe et al. (2019), Livingstone et al. (2017) and Chang et al. (2015). Livingstone et al. (2017), for example, found that fathers and mothers have different feelings which reflect well-defined values. This makes mothers show inclination towards restricting children's access to digital media devices. This finding explains why Livingstone and Helsper (2008) noted that parents apply interaction restriction to deal with children's unwarranted activities. Parents do this through banning emailing, chatting, and instant messaging (IM). They also stop children from online gaming and downloading of films and music, etc. It was not surprising to find that active mediation was also used to a good level. This finding corroborates that of Rasmussen, Ortiz, and White (2015) which suggested that active mediation is beginning to gain popularity among parents as a potent strategy of parental mediation. 
It was not surprising to find that many of the parents studied did not go for technical mediation. This finding corroborates that of Kur, Kolo, and Iorpagher (2019) in a study of parental use of technical mediation at Federal University of Technology, Minna, Niger State, Nigeria, which found low use of technical mediation. A likely explanation for this finding is that parents in developing countries have low digital technology skills, a requirement for technical mediation (Dincer 2012; Durak and Kaygin 2020. It was also not surprising to learn that the parents did not adopt co-use mediation. A likely explanation for this is that the parents, like many other parents in developing countries, are busy with activities that will provide food and other family needs. Thus, many of them have little or no time with their children (Livingstone et al. 2017; Chang et al. 2019; Durak 2020).

\section{b. Consequences of Mediation Strategies adopted by Parents}

Results regarding the success or otherwise of the mediation strategies adopted reveal that all but one (technical mediation) were found to be successful at mediating risks associated with children's use of digital media. The use of restrictive mediation strategy was found to be more successful in mediating children's risky experiences with digital media more than the other strategies. Active and co-use strategies followed in that order. Details of the result are presented in Table 2 below:

Table 2

Respondent's opinion on the success of adopted parental mediation strategies

\begin{tabular}{|c|c|c|c|c|c|}
\hline $\begin{array}{c}\text { Parental } \\
\text { Mediation } \\
\text { Strategy }\end{array}$ & $\begin{array}{c}\text { Very } \\
\text { unsuccessful } \\
\text { F }(\%)\end{array}$ & $\begin{array}{c}\text { Unsuccessful } \\
\text { F }(\%)\end{array}$ & $\begin{array}{c}\text { Successful } \\
\text { F }(\%)\end{array}$ & $\begin{array}{c}\text { Very } \\
\text { Successful } \\
\text { F (\%) }\end{array}$ & $\begin{array}{c}\text { Total } \\
\mathbf{F} \\
(\%)\end{array}$ \\
\hline $\begin{array}{l}\text { Technical } \\
\text { Mediation }\end{array}$ & $40(41.2)$ & $25(25.8)$ & $17(17.5)$ & $15(15.5)$ & $\begin{array}{l}97 \\
(100)\end{array}$ \\
\hline $\begin{array}{l}\text { Restrictive } \\
\text { Mediation }\end{array}$ & $20(8.2)$ & $24(9.8)$ & $41(16.7)$ & $160(65.3)$ & $\begin{array}{l}245 \\
(100)\end{array}$ \\
\hline $\begin{array}{l}\text { Active } \\
\text { Mediation }\end{array}$ & 25 (10.6) & $27(11.5)$ & $58(24.7)$ & $125(53.2)$ & $\begin{array}{l}235 \\
(100)\end{array}$ \\
\hline $\begin{array}{l}\text { Co-use } \\
\text { Mediation }\end{array}$ & $20(12.6)$ & $22(13.9)$ & $38(24.1)$ & $78(49.4)$ & $\begin{array}{c}158 \\
(100)\end{array}$ \\
\hline
\end{tabular}


Table 2 shows respondents' views on how successful/unsuccessful each of the four parental mediation strategies were in mitigating risky experiences of children with digital media. For the dominant strategies, as many as 201 (82\%) respondents indicated restrictive mediation was successful, and $44(18 \%)$ said it was unsuccessful. Similarly, 111 (77.9\%) respondents said active mediation was successful and $52(22.1 \%)$ said it was unsuccessful. For the unpopular strategies, out of the 97 (38\%) respondents who used technical mediation, only 32 (33\%) said it was successful, and a whopping majority (65 or 67\%) said it was unsuccessful. Conversely, out of the 158 respondents who said they were involved in co-use mediation, as many as $116(73.5 \%)$ said it was successful and only 42 $(26.5 \%)$ indicated it was unsuccessful.

This finding agrees with those of previous scholars that restrictive strategy is more meaningful in addressing the risk of cyberbullying, invasion of privacy, and disclosure of web information associated with children (Lwin, Stanaland, and Miyazaki 2008; Mesch 2009; Shin, Huh, and Faber, 2012). Similarly, for Kur, Orhewere, and Agudosy (2011) and Nikken and Jansz (2006), restrictive mediation is also more popular than the other strategies in minimizing the damaging impact of the media on children. However, as noted by other scholars (Livingstone et al. 2017; Chang et al. 2019), when parents place so much emphasis on risks, opportunities or benefits are not derived. This is because as parental restrictions contribute in lowering online risk, online opportunities also go down. This means restrictive mediation also reduces children's benefits with digital media usage. How much benefits it reduces as compared with risks reduction is not clear and is a matter of another research.

What is suggested by the findings of the present study is that, although parents noted they achieved desirable results using both authoritarian (restrictive mediation strategy) and authoritative (Active and co-use meditation strategies) approaches, previous evidence suggests authoritative approaches such as active and co-use mediation are more effective than authoritarian approaches of restrictive and technical mediation strategies (Kur, Orhewere, and Agudosy 2011; Lippold et al. 2014). Restrictive mediation therefore should be used with caution, notwithstanding its effectiveness as found in the present study and previous ones. 


\section{CONCLUSION}

This study investigates strategies adopted by parents in mediating children's risky experiences with digital media, and ascertains the consequences of the mediation strategies. Parental mediation theory was used to explain the study. In relation to the present study, the theory identifies active, restrictive, couse and technical parental mediation strategies as crucial tools used by parents to mediate children's use of digital media so as to minimizing risks associated with the use. The study adopted survey method, with a sample of 265 respondents taken from a population of 863 academic and non-academic staff of Ibrahim Badamasi Babangida University, Lapai. The sample was determined through a combination of proportional sampling, disproportional sampling, purposive sampling, and accidental sampling techniques. Parental Knowledge and Intervention in Children's Risky Experiences with Digital Media Questionnaire (PKICREDMQ) was used to obtain primary data for the study. Findings revealed that an overwhelming majority of the parents said they used mainly restrictive and active strategies in mediating children's risky experience with digital media. A minority number said it used technical and co-use mediation strategies. Most of the respondents who used any of the four parental mediation strategies with the exception of technical mediation, said the strategies were more successful than unsuccessful in mediating children's risky experiences with digital media. The conclusion drawn is that parents actually intervene to alleviate or diminish the negative influences of children's digital media lives. They use mediation approaches that are authoritarian (restrictive mediation) and authoritative (active mediation) in nature. Both of these approaches are effective in mediating negative concerns arising from children's experience with the technology of digital media. This is not withstanding previous findings that authoritative approaches are more advantageous than authoritarian measures in parental intervention in children's use of media technologies.

It is recommended that, in mediating children's risky experiences with digital media, parents should not just stick to restrictive and active mediation strategies; they should consider co-use and technical mediation strategies, depending on the mediation situation (age, experience with digital media, sex, peer influence, and emotions) of the children. Generally, parental mediation 
approaches that are rich in authoritativeness are better and more effective than those that are authoritarian in nature. Parental mediation education should be vigorously pursued in Nigeria and the entire developing countries. This is because the concept of parental mediation is yet to attract the desired knowledge and attention in developing countries. Government, mass media, educational institutions, religious organizations and all other stakeholders in child development should be responsible for the education.

Limitations and Suggestions for Future Research. The study used a limited sample; parents in a university. This scope is limited and restricts wider generalization of findings. Future research should consider a larger scope that cuts across occupational statuses. Similarly, this study did not include the views of children on an issue that concerns them. Future studies will provide more credible results when the views of children on the subject studied are considered side-byside with those of their parents. Furthermore, in a study of this nature, it is expedient to go deeper to understand reasons or factors responsible for the results. Going deeper requires qualitative approaches of data gathering and interpretation. This was not the case in the present study. Future studies should therefore consider complementing quantitative with qualitative approaches in data gathering and interpretation.

The present study, even though focused on Blum-Ross and Livingstone's (2016) four categories of digital media risks (conduct, content, contact and commercial), it treated the risks collectively as one; it did not examine each category of the risks separately. Future studies should examine the different categories of digital media risks specifically and separately. This will provide deeper understanding of associations between the different parental mediation strategies and the different categories of digital media risks. The present study examined each of the four parental mediation strategies from a narrow perspective; it did not examine the different elements of each strategy, but treated the different elements as one. For example, restrictive mediation concerns at least four elements, which are setting rules on (1) the amount of time children use digital media, (2) the time of the day children are allowed to use digital media, (3) accessing certain types of digital media content and not others and (4) punishment given to children who violate the rules. These elements of restrictive mediation were not studied separately. Future studies of this nature should study the 
different elements of a mediation strategy separately. This will expand knowledge of the mediation strategies in respect to children's risky experiences with digital media.

\section{REFERENCES}

Aierba, Ana, Eider Oregui, and Isabel Bartau. 2019. "Video Games, Parental Mediation and Gender Socialization.” Digital Education Review 30: 100116. Retrieved (http://greav.ub.edu/der/).

Bako, Rozalia K., and Gyongyver E. Tokes. 2018. "Parental Mediation and Romanian Young Children's Digital Practices." Revista roman de sociologie XXIX (1-2): 23-36. Retrieved (https://www.revistadesociologie.ro/sites/default/files/03-rozalia_bun.pdf).

Banaji, Shakuntala, and David Buckingham. 2013. "Young People, the Internet and Civic Participation: An Overview of Key Findings from the Civicweb Project." International Journal of Learning and Media 2(1): 15-24. Retrieved (http://eprints.1se.ac.uk/29543/1/Young_People_the_Internet_and_Civic_P articipation(publisher).pdf).

Blum-Ross, Alicia, and Sonia Livingstone. 2016. Families and Screen Time: Current Advice and Emerging Research. Media Policy Brief 17. London: Media Policy Project, London School of Economics. Retrieved (http://eprints.lse.ac.uk/66927/1/Policy\%20Brief\%2017\%20Families\%20 $\% 20$ Screen\%20Time.pdf).

Bottino, Sara M., Cassio M. C. Bottino, Caroline G. Regina, Aline Villa L. Correia, and Wagner S. Ribeiro. 2015. "Cyberbullying and Adolescent Mental Health: Systematic Review”, Cadernos de Saúde Pública 2: 463475. doi:10.1590/0102-311×00036114.

Bruni, Oliviero, Stefanie Sette, Lilybeth Fontanesi, Roberto Baiocco, and Fiorenzo Laghi. 2015. "Technology Use and Sleep Quality in PreAdolescence and Adolescence." Journal of Clinical Sleep Medicine 11(12): 1433-1441. Retrieved (https://europepmc.org/article/pmc/pmc4661336). 
Chang, Fong-Ching, Chiung-Hui Chiu, Nae-Fang Miao, Ping-Hung Chen, ChingMei Lee, Jeng-Tung Chiang, and Ying-Chung Pan. 2015. "The Relationship between Parental Mediation and Internet Addiction among Adolescents and the Association with Cyberbullying and Depression." Comprehensive Psychiatry 57: 21-28. doi:10.1016/j.comppsych.2014.11.013.

Chang, Fong-Ching, Chiung-Hui Chiu, Ping-Hung Chen, Jeng-Tung Chiang, NaeFong Miao, Hung-Yi Chuang, and Shumei Liu. 2019. "Children's Use of Mobile Devices, Smartphone Addiction and Parental Mediation in Taiwan." Computers in Human Behavior 93: 25-32. https://doi.org10.1016/j.chb.2018.11.048

Chassiakos, Yolanda Linda R., Jenny Rodesky, Dimitri Christakis, Megan A. Moreno, and Corinn Cross. 2016. "Children and Adolescents and Digital Media.” Pediatrics 138: 3-11. doi:10.1542/peds.2016-2593.

Clark, Lynn S. 2011. "Parental Mediation Theory for the Digital Age." Communication Theory 21(4): 323-343. Doi:10.1111/j.14682885.2011.01391.x.

Collins, Rebecca A., Victor C. Strasburger, Jane D. Brown, Edward Donnerstein, Amanda Lenhart, and Monique Ward. 2017. "Sexual Media and Childhood Wellbeing and Health." Pediatrics 140(S2): S162-S166. Doi:10.1542/peds.2016-1758X

Dincer, Serkan. 2012. "A Study of the Relationship between Pupils and Parents' Computer Literacy Level and Use." Procedia - Social and Behavioral Sciences 46(2012): 484-489. Doi:10.1016/j.sbspro.2012.05.149

Durak, Aykut and Huseyin Kaygin. 2020. "Parental Mediation of Young children's Internet Use: Adaptation of Parental Mediation Scale and Review of Parental Mediation based on the Demographic Variables and Digital Data Security Awareness." Education and Information Technologies 25: 2275-2296. https://doi.org/10.1007/s10639-019-10079-1

Goh, Wendy L., Sussana Bay, and Vivian H. Chen. 2015. "Young School Children's Use of Digital Devices and Parental Rules." Telematics and Informatics 32(4): 787-795. doi:10.1016/j.tele.2015.04.002.

Guo, Wenxiu, and Amy I. Nathanson. 2011. "The Effects of Parental Mediation of Sexual Content on the Sexual Knowledge, Attitudes and Behaviours of Adolescents in the US." Journal of Children and the Media 5: 358-378. https://www.tandfonline.com/doi/abs/10.1080/17482798.2011.587141. 
Hinduja, Sameer, and Justin W. Patchin. 2010. "Bullying, Cyberbullying, and Suicide." Archives of Suicide Research 14(3): 206-2021. doi:10.1080/13811118.2010.494133.

Ho, Derrick, and Melody Zaccheus. 2012. "Alarm over Population Facebook Groups." The Straits Times, October 23, pp. B1-B2. Retrieved (https://eresources.nlb.gov.sg/newspapers/digitised/issue/straitstimes20121 023-1).

Kemp, Simon. 2018. "Digital in 2018: World's Internet Users Pass the 4 Billion Mark." Retrieved (wearesocial.com/blog/2018/01/global-digital-report2018).

Krejcie, Robert V., and Daryle W. Morgan. 1970. "Determining Sample Size for Research Activities." Educational and Psychological Measurement 30: 607-610. Retrieved (https://home.kku.ac.th/sompong/guest_speaker/KrejcieandMorgan_article .pdf).

Kur, Jude T., and Coleman F. Essien. 2014. "Parental Mediation of Children's Cell Phone Use: Motives, Strategies and Effects." Asian Congress for Media and Communication 2014 Conference Proceedings. Retrieved (www.asianmediacongress.org/2014Confab-B.htm).

Kur, Jude T., Joan W. Kolo, and Martha M. Iorpagher. 2019. "Parental Controls and Mediation of Children's Digital Media Use: A Study of Parents at Federal University of Technology, Minna, Nigeria." Journal of Mobile Computing and Application 6(6): 1-11. DOI: 10.9790/0050-06060111.

Kur, Jude T., John A. Orhewere and Fabian I. Agudosy. 2011. "Parental Involvement and Mediation of Children's TV Viewing." International Journal of Sustainable Development 4 (4): 11-26.

Kur, Jude T., Martha M. Iorpagher, and Bernard B. Melladu. 2019. "New Media Technologies and Political Socialization of Children: The Exigency of Parental Mediation." Journal of Humanities and Social Sciences 24(12) Series 5: 6-16. DOI: 10.9790/0837-2412050616.

Lemola, Sakari, Nadine Perkinson-Gloor, Serge Brand, Julia F. DewaldKaufmann, and Alexander Grob. 2015. "Adolescents' Electronic Media Use at Night, Sleep Disturbance, and Depressive Symptoms in the Smartphone Age." Journal of Youth and Adolescence 44(2): 405-418. doi.org/10.1007/s10964-014-0176-X. 
Lippold, Melissa. A., Mark T. Greenberg, John W. Graham, and Mark E. Feinberg. 2014. "Unpacking the Effect of Parental Monitoring on Early Adolescent Problem Behavior: Mediation by Parental Knowledge and Moderation by Parent-Youth Warmth. ” Journal of Family Issues 35: 1800-1823. doi: 10.1177/0192513X13484120.

Livingstone, Sonia, and Ellen J. Helsper. 2008. "Parental Mediation of Children's Internet Use." Journal of Broadcasting \& Electronic Media 52(4): 581599. doi:10.1080/088381 50802437396.

Livingstone, Sonia, Giovanna Mascheroni, and Elisabeth Staksrud. 2017. "European Research on Children's Internet Use: Assessing the Past, Anticipating the Future." New Media \& Society. https://doi.org/10.1177/1461444816685930.

Livingstone, Sonia, Giovanna Mascheroni, Michael Dreier, Stephane Chaudron, and Kaat Lagae. 2015. How Parents of Young Children Manage Digital Devices at Home: The Role of Home Income, Education and Parental Style. London, UK: EU Kids Online, LSE. Retrieved (https://www.lse.ac.uk/media@1se/research/EUKidsOnline/EUKidsIV/PD F/Parentalmediation.pdf).

Livingstone, Sonia, Kjarton Olafsson, Ellen J. Helsper, Francisco LupianezVillanueva, Giuseppe A. Veltri, and Frans Folkvord. 2017. "Maximizing Opportunities and Minimizing Risks for Children Online: The Role of Digital Skills in Emerging Strategies of Parental Mediation. ” Journal of Communication 67(1): 82-105. doi:10.1111/jcom.12277.

Lwin, May O., Andrea J. S. Stanaland, and Anthony D. Miyazaki. 2008. "Protecting Children's Privacy Online: How Parental Mediation Strategies affect Website Safeguard Effectiveness." Journal of Retailing. doi10.1016/j.jretai.2008.04.004.

Mesch, Gustavo O. 2009. "Parental Mediation, Online Activities, and Cyberbullying." CyberPsychology \& Behavior 12(4): 387-393. doi.org/10.1089/cpb.2009.0068.

Moreno, Megan A., Adrienne Ton, Ellen Selkie, and Yolande Evans. 2016. "Secret Society 123: Understanding the Language of Self-Harm on Instagram." Journal of Adolescent Health 58(1): 78-84. doi: 10.1016/j.jadohealth.2015.09.015.

Nathanson, Amy I. 1999. "Identifying and Explaining the Relationship between Parental Mediation and Children's Aggression." Communication Research 26(6): 124-143. 
Nikken, Peter, and Jeroen Jansz. 2006. "Parental Mediation of Children's Videogame Playing: A Comparison of the Reports by Parents and Children." Learning, Media and Technology 31(2): 181-202. doi:10.1080/17439880600756803.

Nikken, Peter, and Jeroen Jansz. 2014. "Developing Scales to Measure Parental Mediation of Young Children's Internet Use." Learning, Media and Technology 39 250-266. http://dx.doi.org/10.1080/17439884.2013.782038.

Rasmussen, Eric E., Rebecca R. Ortiz, and Shawna R. White. 2015. "Emerging Adult Responses to Active Mediation of Pornography during Adolescence." Journal of Children and Media 9(2): 160 - 176. Doi:10.1080/17482798.2014.997769.

Robert, Lindsay, Helena M. McAnally, and Robert J. Hancox. 2013. “Television Viewing and Antisocial Behaviour in Early Adulthood." Pediatrics 131(3): 439-446. DOI:10.1542/peds.2012-1582

Sasson, Hagit, and Gustavo Mesch. 2014. "Parental Mediation, Peer Norms and Risky Online Behaviour among Adolescents." Computers in Human Behavior 33(2014): 32-38. http://dx.doi.org/10.1016/j.chb.2013.12.025.

Shin, Wonsun, Jisu Huh, and Ronald J. Faber. 2012. "Tweens' Online Privacy Risks and the Role of Parental Mediation." Journal of Broadcasting \& Electronic Media 56(4): 37-41. http://www.tandfonline.com/doi/abs/10.1080/08838151.2012.732135.

Smahelova, Martina, Dana Juhova, Ivo Cermak, and David Smahel. 2017. "Mediation of Young Children's Digital Technology Use. The Parents' Perspectives." Cyberpsychology: Journal of Psychosocial Research in Cyberspace 11(3): 1-7. https://dx.doi.org/10.5817/cp2017-3-4.

Tripp, Lisa M. 2011. "The Computer is not for You to be Looking Around, it is for Schoolwork: Challenges for Digital Inclusion as Latino Immigrant Families Negotiate Children's Access to the Internet." New Media \& Society 13(4): 552-567. Doi: 10.1177/1461444810375293. 
Valkenburg, Patti M., Marina Krcmar, Allerd L. Peeters, and Nies M. Marseille. 1999. "Developing a Scale to assess Three Styles of Television Mediation: Instructive Mediation, Restrictive Mediation, and Social Coviewing." Journal of Broadcasting and Electronic Media 43(1): 52-67. https://doi.org/10.1080/08838159909364474.

Warren, Ron. (2005). "Parental Mediation of Children's Television Viewing in Low-Income Families." Journal of Communication 55(1): 847-863. https://doi.org/10.1111/j.1460-2466.2005.tb03026.x.

Watkins, Jon. 2019. "Africa: A Digital Coming of Age.” Retrieved (whatsnewinpublishing.com/Africa-a-digital-coming-of-age). 